\title{
FINDING METACULTURE IN NARRATIVE: \\ THE CASE OF DIASPORIC JAPANESE IN THE UNITED STATES
}

\author{
Masataka Yamaguchi
}

\begin{abstract}
I am concerned with finding a widely circulating ideology in life story narratives told to me by three diasporic Japanese in the United States. By drawing on discourse analytic perspectives, I analyse audio-recorded interview data as 'cultural objects' and extract participants' 'ideology' from the 'objects'. In so doing, I attempt to find widely circulating and relatively enduring values in the discourses of these narratives. By analytically focusing on contextually contingent aspects of language use, I make explicit the pattern of the 'success story line'. These findings are then compared with another study on autobiographical narrative. While qualifying the generalisability of the findings, I argue that my own study proposes a hypothesis that deserves further investigation in providing a concrete piece of evidence against the idea of 'postmodern fragmented subjects' (Jameson 1984).
\end{abstract}

\section{INTRODUCTION}

This study is concerned with finding metaculture in life story narratives and explicitly adopts and adapts its title from the edited work of Naomi Quinn (2005) entitled Finding Culture in Talk: A Collection of Methods. For my purposes, I conceptualise culture as circulation, or 'metaculture' (Urban 2001) by drawing on a 'discourse-centred approach' (Sherzer 1987). By the term 'metaculture', I refer to widely circulating and relatively enduring beliefs, values, and ideas in society, which consist of 'judgments people make about similarities [between] and differences [in]' material cultural objects (Lee 2001: xi). In short, it is 'a second order form of semiotic self-reflexivity that helps frame first-order processes' (ibid $x i$ ), an idea which I will further elaborate below.

Metaculture widely circulates in society because of its 'accelerative' forces, while it is relatively enduring because of its 'inertial' character (Urban 2001:5- 
20). It is immaterial but extractable from material cultural objects, whether the objects are traditional Amerindian myths or modern Hollywood films. Specifically, the former is disseminated through exact replications (i.e., re-tellings of the 'same' myth that one has heard before) under a 'metaculture of tradition' (Urban 2001: 83-92). In contrast, the latter moves through social space by the interest it generates or by its 'newness' under a 'metaculture of modernity' (ibid: 1-6). Thus, film reviews as a metacultural commentary play a crucial role in disseminating the films under review. The dissemination of the films does not rely on replication, but on 'the transmission of the kinds of meanings contained in or carried by the cultural object' (Urban 2001:239).

In this study, I analyse audio-recorded and transcribed interview data as 'cultural objects' and extract from the data my participants' 'ideology' that frames their talk. As a case study, I concentrate upon how three diasporic Japanese narrate their personal life experiences in interviews conducted in the United States. The analysis of the interviews demonstrates how an often tacit 'metacultural frame' is actually embodied as a systematic pattern in the ongoing processes of interaction, which is called 'poetic structure' (Silverstein 1985).

To clarify two technical terms, let me explain the concepts of 'poetic structure' and 'metacultural frame' by way of exemplification. Wortham (2001: 76-135) analyses an elicited narrative in a research interview between Jane in her midfifties and a psychology graduate student in the United States, part of which is reproduced in Table 1 . The numbers in the parentheses indicate the lines in the transcript:

Table 1. Part of Jane's narrative (Wortham 2001)

\begin{tabular}{|l|l|}
\hline I was regarded as other (117) & I ran away (131) \\
I was ostracized (118) & I went there (132) \\
$\begin{array}{l}\text { I jumped from one space of being } \\
\text { ostracized into another (122-123) }\end{array}$ & I ran away (132) \\
$\begin{array}{l}\text { My mother thought that it would be best } \\
\text { that I be placed in a private school (125) }\end{array}$ & I went to the drug store (132-133) \\
$\begin{array}{l}\text { I was there for a year and a half (130) } \\
\begin{array}{l}\text { Evidently my character was being } \\
\text { developed (130-131) }\end{array}\end{array}$ & I refused to tell her (134) \\
\hline
\end{tabular}


As can be seen, the utterances on the left column can be characterized by the use of be (or 'copular verb') and/or the passive form ('was regarded,' 'was ostracized,' or 'was there,' etc.) while those on the right column contain verbs that represent actions ('ran away,' 'went,' or 'called,' etc.). The patterning is indicated or cued by these particular combinations of $I$ and verbs, in addition to other semiotic (i.e., linguistic and other culturally meaningful) resources. They include grammatical devices such as past tense, as well as a tone of voice or an act of crying, the latter being absent in the above table (but see Wortham 2001:76-135). The combinations of cues are systematic and interlocking so that we can see coherence in the narrative told by Jane. This kind of patterned structure I call 'poetic structure,' a term first proposed by Roman Jakobson (1960) and further developed by Michael Silverstein $(1985,1997)$. Furthermore, we see that the narrative is told from a particular perspective or 'framed' in a way that Jane changed from passive to active states. I call the framing function of language 'metadiscursive' because we must use a second-order, higher-level, or 'meta-discourse in order to produce coherent discourse in the interaction. In addition, I use the related term 'metacultural' if a particular pattern of framing is presumed to be widely circulating in society.

In relation to the present study, I illustrate a metadiscursive frame, which is realized as a 'success story line,' by analytically focusing upon contextually contingent aspects of language and the personal pronoun ' $I$ ' in particular. Furthermore, in this paper, I assume, following Jakobson, Silverstein, Wortham, and others, that any utterance has multiple functions, and serves at least three functions: (1) to describe states of affairs (or 'refer-to-and-predicate-about states of affairs'), (2) to position speaker and addresse(s) interactionally, and (3) to cohere with other utterances and widely circulating (meta)discourses. It should be noted at this point that I particularly attend to the second 'interactional' function of language in relation to the other two, and in order to do so, it is useful to focus on personal pronouns because of their inherently 'indexical' nature. By 'indexicality', I mean 'the pervasive context-dependency of natural language utterances' (Hanks 2001:124), and thus any linguistic form has an 'indexical' character since it needs to get its meaning from the context of use. However, pronouns are inherently 'indexical' since they need contextual specification in order to become interpretable. For example, the pronoun we can mean 'the speaker and the addressee speaking at the moment' (e.g., 'Have we met before?') or 'all the human beings in the world' (e.g., 'We are in danger of extinction because of the threat posed by nuclear weapons on earth'). Finally I assume that by analytically attending to pronouns in an interactional context, we can not only understand the referential and the interactional functions, 
but also the metadiscursive function that frames situated discourse, a point to which I will return in the section on Theoretical Background.

The major findings of the analysis can be summarized as follows: all the three diasporic Japanese implicitly used the metadiscursive frame of a 'success story line' while telling their life story narratives in interviews. In so doing, they discursively constructed unsuccessful or struggling selves in the past, while contrastively constructing successful selves, who were spatio-temporally closer to the present story-telling self. I compare the findings with those of Wortham $(2001,2003)$ in which we see a comparable 'two-part developmental metadiscourse' in a narrative told by a middle-aged woman in the United States. Thus, I present a hypothesis that the metadiscursive frame of a 'success story line' is a widely circulating one and represents a dominant or 'hegemonic' ideology in society.

While qualifying the generalisability of my findings in distributional-statistical terms, I argue that this study proposes the hypothesis of the success story line widely circulating in society, which deserves a further investigation. Also I provide concrete and clear empirical evidence against 'postmodern fragmented subjects' (Jameson 1984, Strauss 1997), as well as implications for how to conceptualise complex relationships among language, ethnicity, and national identity in late modernity.

\section{WHAT IS THE PROBLEM?}

In this section, I discuss the problematics of research interviews that motivated the present study, and then situate them within a broader intellectual landscape, which is often characterized as 'late modernity' or 'postmodernity' After considering the wider issues, I set up three specific research questions that I will answer in the sections that follow.

Charles L. Briggs, in his 2003 book chapter, 'Interviewing, Power/Knowledge, and Social Inequality', perceptively warns us against the danger of research interviews, which is the (re)production of knowledge that serves the interests of the dominant groups in society. ${ }^{1}$ Specifically, research interviews are predominantly conducted in marginalized populations with asymmetric power relations between researcher and researched. Thus, we should be aware of the possibilities for 'constructing a 'minority voice' that confirms the hegemonic status quo' (Briggs 2003:244). In other words, the uses of interviews in social sciences may contribute to (re)producing knowledge, power, and inequality in modern society. While recognizing the danger, we should not abandon inter- 
viewing as a research method, as Briggs argues. Instead we should investigate 'the circulation of discourse' (ibid: 246), rather than focusing only on interview settings themselves. It should also be noted that the shift of focus from the settings to the circulation of discourse by Briggs is inspired by such poststructuralists as Foucault (1980) and Bourdieu (1991), whose concerns are with power and inequality in modern institutions in late or post-modernity.

Having situated my study within the larger context, we still do not know precisely how to identify 'concretely the discursive and institutional means by which this circulation takes place ... [and] trace it in particular instances' (Briggs 2003: 248). In other words, while the analytic focus is on widely circulating discourses, how can we identify them in specific discursive interactions such as research interviews? I will answer this question by conceptualising interviews as situated social practice, and make three specific research questions:

1. How do we know that a particular metadiscursive frame is operating in a given interaction?

2. How do we know that a particular metadiscursive frame is widely circulating in society?

3. What are the implications of the findings for understandings of 'postmodernity,' with particular reference to the concept of 'fragmented postmodern subjects' (Jameson 1984)?

I will provide tentative answers to these questions while analysing narratives which were taken from research interviews between three diasporic Japanese participants and this author (serving also as the interviewer) in the United States. In order to analyse the data, however, I need a theoretical lens through which to view them, and my theoretical background is formally presented in the next section, though my theoretical assumptions of functions of language were already discussed in the introduction.

\section{THEORETICAL BACKGROUND}

My theoretical background for data analysis derives from two traditions: One is linguistic anthropology (LA), which is defined as 'the study of language as a cultural resource and speaking as a cultural practice' (Duranti 1997:2). The other is critical discourse analysis (CDA), which is primarily concerned with language, power, and ideology in late modern capitalist society (Fairclough 1989, 1992; Kress and Hodge, 1979; Hodge and Kress 1988). 
In linguistic anthropology, I particularly draw on a theoretical perspective designated as 'Natural Histories of Discourse' (NHD), which focuses on situated language use in relation to larger sociohistorical processes, and distinguishes three functions of language (Silverstein and Urban 1996:1-17): referentialdenotational, which is also called 'propositional meaning, and refers to the function of language that describes states of affairs; indexical-interactional, which is the meaning that derives from situations of language use or situationally-contingent meaning; and metadiscursive, which refers to the 'meta' function and frames the situated language use as a particular type of event. It should be briefly noted that the tripartite scheme is similar to that of Fairclough (1992: 63-100) in distinguishing three 'dimensions' of discourse as text, discursive practice, and social practice.

NHD can be situated within the broader framework of 'a discourse-centred approach to culture' (Sherzer 1987, Urban 1991) in US anthropology. As Edward Sapir argued as early as in 1938 in the original publication: 'The true locus of culture is in the interactions of specific individuals and, on the subjective side, in the world of meaning which each one of these individuals may unconsciously abstract for himself from his participation in these interactions' (Sapir 1949:572). The idea is developed further by Joel Sherzer in his designation of the Sapirian approach as a 'discourse-centred approach to culture', noting that ' $[s]$ ince discourse is an embodiment $[a n d]$... a transmitter of culture, then in order to study culture we must study the actual forms of discourse produced and performed by societies and individuals, ... that constitute a society's verbal life' (Sherzer 1987:306). Furthermore, from a semiotic-anthropological perspective, Greg Urban conceives culture as '[being] localized in concrete, publicly accessible signs, the most important of which are actually occurring instances of discourse' (Urban 1991:1).

The discourse-centred approach directs our attention to situated interaction by highlighting 'indexical' or situationally-contingent aspects of language use, as well as referential-denotational aspects. However, my concern is much broader, which is to investigate how power and inequality are (re)produced in and through discourse in late modernity.

In order to adequately conceptualise 'metadiscursive' or macro-sociological aspects of discourse, I draw on Critical Discourse Analysis (CDA) that has been concerned with language, power, and ideology from 'top-down' perspectives. In this study, I am concerned with ideology in the sense of 'a systematic body of ideas, organized from a particular point of view' (Kress and Hodge 1979: 6). We should also recognize that ideology has contradictory characteristics. In 
other words, it presents different images of the world depending on the perspective of a 'dominant' group (rulers, exploiters, etc.) or that of a 'dominated' group (ruled, exploited, etc.). Thus, as Hodge and Kress argue, ideology should be seen as 'an ideological complex' or 'a functionally related set of contradictory versions of the world' (Hodge and Kress 1988:3) by recognising multiplicities of ideology.

Moreover, I am sensitised by an analytic focus on a particular kind of ideology in CDA, which is Gramscian hegemony. According to Fairclough, hegemony is 'leadership as much as domination ...through concessions or ... ideological means to win [dominated groups'] consent', (Fairclough 1992: 92) but for my purposes, the most important aspect of hegemony is its implicit and commonsensical character. By conceptualising ideology and hegemony in this way, I can direct my attention to a particular kind of 'metaculture,' which is a widely circulating and relatively enduring dominant ideology, but is not felt as 'ideology' because of its taken for granted or hegemonic character.

More specific to the research context, I use the concept of life story narrative, which is defined as 'the iconic match between a sequence of narrative clauses and a sequence of events' about one's life (Hill 2005:157). The major purpose of using this concept is to reveal 'the covert underlying presuppositions that organize the worlds' (ibid:157) of the narrators, which emerge in situated interactions. The presuppositions may be reflexively related to metaculture if there are systematic patterns in metadiscursive framing across the participants. In the analysis, I look at two particular points. The first is how personal pronouns, such as 'I,' 'we,' or 'they', are used in combination with other semiotic resources in the situated interaction. As I discussed in the introduction, the pronouns are inherently indexical resources, the meaning of which is crucially bound up with the context of use. The other focus is on 'contextualization cues' or 'any verbal sign which ... serves to construct the contextual ground for situated interpretations' (Gumperz 1999:461). Some examples of these cues are prosody, paralinguistic signs, code choice, choice of lexical forms or formulaic expressions, and verb tense and aspect (Gumperz 1992: 230-235). Among them, I make special reference to lexical choice or collocation patterns of verbs with personal pronouns, verb tense and aspect, and prosodic features and particularly what in the folk terminology is called 'accent.'

\section{RESEARCH CONTEXT}

During the initial phase of a larger project entitled A Critical Study of Discursive Practices of 'Othering' in the Construction of National Identities: The Case of 
Learners of Japanese as a Foreign Language (see Yamaguchi 2005), I conducted research interviews with two participants (Shoko and Marco) in 2002 and 2003. In addition, I interviewed one more participant (Yoko) during the final phase of the project in 2004. They all had the experience of studying Japanese as a heritage language. It should be noted that the first two participants (Shoko and Marco) were not born in the United States (Shoko in England, and Marco in Japan), while the third (Yoko) was born in Atlanta, Georgia and also had American nationality at the time of interviewing. Though the names are pseudonyms, Yoko had a Japanese family name as did Shoko, while Marco had an Italian first name and a Japanese family name. Shoko and Yoko were around 20 years old, and Marco around 30 years old. This author as the researcher, born and brought up in Japan, was in his thirties and had lived in the United States for about four to six years when the interviews were conducted. All of the participants were recruited on a voluntary basis using my personal networks in a college community located in the southeast of the United States.

Their profiles are summarized in Table 2 below. I am aware that the representation of 'ethnicity' is highly problematic particularly for Marco: he was born to a Japanese father and a German mother, and thus I put the labels of 'Mixed' and 'Euro-Asian' in the section. Of course, I recognise that there is no such thing as 'pure Japanese' or 'pure race' in genetic-biological terms. However, rather reluctantly, I use the folk terminologies from the necessity to describe the participants' profiles as a reference point:

Table 2. Profiles of the participants

\begin{tabular}{|l|l|l|l|}
\hline $\begin{array}{l}\text { Names of } \\
\text { participants }\end{array}$ & Shoko & Yoko & Marco \\
\hline Gender & Female & Female & Male \\
\hline Ethnicity & Asian & Asian & Mixed (Euro-Asian) \\
\hline Nationality & Japanese & American-Japanese & Japanese \\
\hline
\end{tabular}

\section{DATA ANALYSIS}

In this section, I first present Shoko's life story narrative in detail, which is divided into three segments, and analyse her narrative by focusing on the pronoun $I$, in combination with the predicate verb in each token, based on 'I-statements analysis' (Gee 1999: 124-130). After the analysis, I recast the patterning of I-statements in terms of different 'types of 'I's' from a semiotic perspective (Urban 1989). I will show how different 'I's are instantiated in her 
narrative discourse, which, in combination with other indexicals, constitutes a metadiscursive pattern of 'success story'. Then, I compare her pattern with those of Yoko and Marco in order to see whether there is any common patterning among the three, which can be hypothesized as 'metaculture.'

More specifically, five different 'types of 'I's' are analytically separated in terms of 'removal from every day situation' (Urban 1989:43): (a) indexical-referential $I$ in which there is an actual contiguity between the type $I$ and the producer of the token 'I' (ibid: 28); (b) anaphoric $I$, which is embedded within a direct quotation (ibid:31); and (c) de-quotative $I$ or the 'I' of a quotation with no matrix clause, which is cued by the past tense in story-telling (ibid:36). I am only concerned with these three types although Urban further distinguishes between (d) theatrical $I$ speaking through the character on the stage in theatre and (e) projective $I$ in the state of trance, possession, or similar states. It should be noted that (a) is closest to 'everyday self' while (b) is 'quoted self', as in 'He said, "I am going"'. Finally, (c) is the same as (b) except for having no matrix clause and is used as 'story telling self' in narrative, for example.

At the beginning of each interview I started with asking each participant to tell a life story narrative, which was cued by 'Could you tell me a story about your life?' Shoko started her story in the following way:

Uh well first I, I was born in England so and then uh so we moved from England to Japan when I was three. So then we we we uh moved to where our grandparents lived for a couple of years until we built a house in uh Kanagawa.

Then, Shoko continues as follows; I have boldfaced the I-statements for the analytic focus: $^{2}$

(1a) Shoko's schooling experience in Japan:

1 Shoko: And then, (0.5) First ah, first grade, um, I didn't like school

2 be $[$ cause $=$

3 Masa: [(laugh)

4 Shoko: =um

5 Masa: why? why not?

6 Shoko: because I just didn't like it (laugh) and, ah, (1.0)we had groups

7 of people going to school together=

8 Masa: =Uh huh you didn't like that

9 Shoko: and yeah I didn't like that. Ah, yes, I didn't like the neighbors, 
well they were, they were my friends but they were very, ah=

11 Masa: =Mean? Or

12 Shoko: Ni:ce?, I guess, they were kind of mean but I mean, they were so

14 Masa: O.K.

15 Shoko: And then so I didn't like that so I didn't want to go to school 16 so my teachers-(Shoko's talk continues)

Adapting Gee's scheme, I label the tokens of $I$ in collocation with predicates as: 'cognitive statement' (e.g. 'I didn't know English'); 'affective statements' (e.g. 'I didn't like the neighbors'); 'state and action statements' (e.g. 'I was scared'); 'ability and constraint statements' ('I had to go to middle school'); and finally, 'achievement statements' or achievements that count as 'mainstream' middle-class success at school, such as 'I made lots of friends' (Yamaguchi 2005). Data (1a) entitled 'Shoko's schooling experience in Japan' is characterized by affective statements:

Table 3. Shoko's I-statements for her schooling experience in Japan

\begin{tabular}{|l|l|}
\hline I-statements (number of tokens): & Types/Grammatical Form \\
\hline I didn't like school (1): & Affective/Negative \\
\hline I just didn't like it (1): & Affective/Negative \\
\hline I just didn't like that (2): & Affective/Negative \\
\hline I didn't like neighbors (1): & Affective/Negative \\
\hline I didn't like them too much (1): & Affective/Negative \\
\hline I didn't want to go to school (1): & Affective/Negative \\
\hline
\end{tabular}

Shoko goes on to narrate her first schooling experience in the United States, to which she immigrated at the age of thirteen in the sixth grade. I analyse the relevant I-statements in the segment that follows:

(1b) Shoko's first schooling experience in the United States:

1 Shoko: $\underline{\text { So, }}$ sixth grade I didn't talk one bit in school. [um,

2 Masa: [Oh really?

3 Shoko: First of all because I- I was I didn't know English, and then

$4 \quad$ second of all 'cause I didn't want to:? because I was scared

5 what other kids were gonna think of me. so [I =

6 Masa: [Oh 
7 Shoko: =just I just didn't say anything. And then so, graduated

8 from fifth grade and I had to go to middle school, but the

9 middle school that I was supposed to go to, um, didn't have

10 ESL- OL program, so I had to go to another school where it

11 had it-, had one.=

12 Masa: mmhm

13 Shoko: =so I had to go probably like thirty minutes away from my

14 house.

15 Masa: $\mathrm{mmhm}$

16 Shoko: out of the way. and then, um, so, brand new school brand new

17 people, I [didn't know=

18 Masa: $\quad[\mathrm{mmhm}$

19 Shoko: =any[thing?=

20 Masa: $\quad[\mathrm{mmhm}$

21 Shoko: =and then so I was scared, and, ah-, cried most of the time

$22 \rightarrow \quad$ 'cause I didn't want to go to school. Um, and then my

23 English progressed a:nd [then=

24 Masa: [oh

Table 4. Shoko's I-statements for her first schooling experience in the United States

\begin{tabular}{|l|l|}
\hline I-statements (number of tokens): & Types/Grammatical Form \\
\hline I was scared (4): & Stative/Assertive \\
\hline I didn't talk one bit in school (1): & Action statement/Negative \\
\hline I didn't know English or anything (1): & Cognitive/Negative \\
\hline I didn't know English (3): & Cognitive/Negative \\
\hline I didn't know anything (1): & Cognitive/Negative \\
\hline I had to go to another school (1): & Constraint/Assertive \\
\hline $\begin{array}{l}\text { I had to go to probably thirty minutes } \\
\text { away from my house (1): }\end{array}$ & Constraint/Assertive \\
\hline [I] cried most of the time (1): & Action/Assertive \\
\hline I did not want to go to school (1): & Affective/Negative \\
\hline
\end{tabular}

The most frequently occurring I-statement is the stative 'I was scared' (four times), which is causally connected with her lack of knowledge in English as instantiated by the cognitive I-statement 'I didn't know English' (three times) in her narrative. However, the problem is logically resolvable if she acquires the knowledge of English. In fact, at lines 22 and 23, it is resolved in Shoko nar- 
rating: 'Then my English progressed,' which is a turning point in her narrative. Now, I turn to the latter half of her schooling experience in the United States:

(1c) Shoko enacting successful 'I's' in the United States:

23 Shoko: =I graduated from the program.

24 Masa: mmhm

25 Shoko: in sixth gra- end of- end of sixth grade. : and the:n, seventh

26 grade was very fun cause I made lots of friends. [and=

27 Masa:

$[\mathrm{mmhm}$

28 Shoko: =eighth grade was really fun too, [and=

29 Masa:

$[\mathrm{mmhm}$

30 Shoko: =high school I did lots of extracurricular [activities,

31 Masa:

$[\mathrm{mmhm} . \mathrm{mmhm}$

32 Shoko: =I played soft $[$ ba:ll=

33 Masa: [yes

34 Shoko: =and tra:ck and, uh, I played soccer? and like (unintelligible)

35 club and all that stuff so, overall this experience here is- been

36 a great [experience. $=$

37 Masa: [O.K.

38 Shoko: ='cause I succeed $[$ ed $=$

39 Masa: $\quad[\mathrm{mmhm}$

40 Shoko: ='cause if I was in Japan then I probably wouldn't have 41 grown this much.

42 Masa: Oh.

Table 5. Shoko enacting successful 'I's' in the United States

\begin{tabular}{|l|l|}
\hline I-statements (number of tokens): & Types/Grammatical Form \\
\hline I graduated from the [ESOL] program (1): & Achievement/ Assertive \\
\hline I made lots of friends (1): & Achievement/ Assertive \\
\hline I did lots of extracurricular activities (1): & Achievement/ Assertive \\
\hline I played softball and track (1): & Achievement/ Assertive \\
\hline I succeeded (1): & Achievement/ Assertive \\
\hline $\begin{array}{l}\text { I probably wouldn't have grown this much } \\
(1):\end{array}$ & $\begin{array}{l}\text { Achievement/ Subjunctive } \\
\text { Mood }\end{array}$ \\
\hline
\end{tabular}


As can be seen above, Shoko successively makes achievement I-statements after the turning point, which ends with subjunctive mood at lines 40-41: 'if I was $[$ sic] in Japan then I probably wouldn't have grown this much.'

Let me recast the I-statements analysis in semiotic-pragmatic terms. It can be seen that 'four voices' as four different tokens of 'I's' are enacted by Shoko. Three 'I's' in the past are enacted by the de-quotative type $I$ or 'reported self' cued by past tense, and they are: (a) the 'unsuccessful 'I" in Japan in (1a), (b) the 'struggling 'I" before learning English in the United States in (1b), and finally (c) the "successful "I" after learning English in US in (1c). The fourth voice is (d) the "speaking ' $\mathrm{I}$ " at the moment of interview as a token of indexicalreferential type $I$. It should be noted that the successful 'I' is functionally and chronologically closer to the speaking ' $I$ ', while the unsuccessful 'I' in Japan is most remote and least related to the indexical-referential $I$ at present.

Having analysed Shoko's narrative in denotational and interactional terms, the question that I now need to ask is metadiscursive. What kind of metadiscursive frame is operating in the interaction? In other words, the indexical cues analysed above collectively presuppose each other to frame her telling narrative as a particular kind of event. What kind of event is it? What is 'going on' in the interview? Following the evaluative utterance by Shoko at line 38 ('I succeeded'), I interpret it as Shoko telling a 'success story' to the interviewer. Thus I tentatively label the metadiscursive frame as 'a success story line.' Now I turn to Yoko's life story narrative, which is presented only partially below in order to save space:

(2) Yoko's life story narrative

1 Yoko: Um, well? $\underline{I}$ was born in Atlanta Georgia?. in 1983. umm (0.5)

2 lets see er, I was born in (unintelligible) hospital [(hhhh).

3 Masa:

(after several turns)

4 Yoko: =Um hum. I applied for a couple of colleges but

5 unfortunately I didn't get into any of them. (unintelligible

6 utterance) and my parents were pretty [thrilled that I got into

7 Masa: [Um hum.

8 Yoko: (X University), so I can keep the scholarship. So I'm here 9 right now studying finance.

As for the previous excerpt, I then analysed I-statements for lines 44-49: 
Table 6. Yoko's I statements in her life story narrative

\begin{tabular}{|l|l|}
\hline I-statement (number of tokens) & Types/ Grammatical Form \\
\hline I applied for a couple of colleges (1): & Action/Assertive \\
\hline I didn't get into any of them (1): & Action/Negative \\
\hline I got into [X university] (1): & Achievement/Assertive \\
\hline I can keep the scholarship (1): & Ability/Assertive \\
\hline I am her right now studying finance (1): & Achievement-State/Assertive \\
\hline
\end{tabular}

In her narrative, Yoko first constructs two 'unsuccessful 'I's' at lines 44-45 ('I applied for a couple of colleges but unfortunately I didn't get into any of them'), which are tokens of de-quotative $I$. However, at lines 46 and 48-49, she constructs two 'successful 'I's' ('I got into [the name of the university she is attending]' and 'I can keep the scholarship', which are tokens of de-quotative $I$, but functionally closer to the 'speaking ' $\mathrm{I}$ " at the moment. The speaking ' $\mathrm{I}$ ' is enacted at lines $48-49$ (' $I$ ' $\mathrm{m}$ here right now studying finance') as a token of the indexical-referential type $I$.

If the question of a metadiscursive frame is asked for Yoko's narrative, it is plausible to posit 'a success story line' as in Shoko's narrative. The space prevents me from presenting Marco's narrative in detail. Thus I present only the I-statements analysis made for Marco's narrative:

Table 7. Macro's past experience in Japan

\begin{tabular}{|l|l|}
\hline I-statements (number of tokens) & Types / Grammatical Form \\
\hline $\begin{array}{l}\text { I had a couple of Japanese friends in elementary } \\
\text { school, actually Japanese people I knew (1): }\end{array}$ & State/ Assertive \\
\hline I didn't look Japanese (2): & State/ Negative \\
\hline I was like this foreigner kind of thing (1): & State/ Assertive \\
\hline I didn't speak English too well (1): & Ability as constraint/ Negative \\
\hline $\begin{array}{l}\text { I didn't understand them [=Americans], either } \\
\text { (1): }\end{array}$ & Ability as constraint/ Negative \\
\hline I was very quiet, acquiescent (1): & State/ Assertive \\
\hline $\begin{array}{l}\text { I was very, not submissive but less flamboyant } \\
\text { than I am now (1): }\end{array}$ & $\begin{array}{l}\text { State/ Non-Assertive in } \\
\text { Comparative Construction }\end{array}$ \\
\hline
\end{tabular}


Table 8. Marco's articulation of the present self

\begin{tabular}{|l|l|}
\hline I-statements (number of tokens) & Types of I-statement \\
\hline I feel like I am a very enriched person (1): & Cognitive/ Assertive \\
\hline I come across as a very cosmopolitan (1): & State/ Assertive \\
\hline $\begin{array}{l}\text { I also come across as a very international, } \\
\text { well-traveled (1): }\end{array}$ & State/ Assertive \\
\hline I am interested in a lot of things (1): & State/ Assertive \\
\hline I can see connections with everything else (1): & Ability/ Assertive \\
\hline I bring in Eastern principles (1): & Action/ Assertive \\
\hline
\end{tabular}

As can be seen, Marco negatively represents his past selves in Japan in the statements listed in Table 7, which are enacted by the de-quotative $I$ cued by past tense, while positively representing the present selves in the statements in Table 8 with the indexical-referential $I$ in the present tense. Though his past representation is different from the two in his racialised experience in Japan ('I didn't look Japanese' and 'I was like this foreigner kind of thing'), a success story line as a metadiscursive frame is also applicable to his narrative. Therefore, I posit a 'success story line' as a local metacultural frame, which operates in the interviews among the three participants.

Now, if I am right by positing that the metaculture of 'success story line' is circulating in the local context, I should ask how widely it is circulating in society, which is an empirical question. In order to answer it rigorously, therefore, I need to conduct interviews with a statistically significant number of participants and/or conduct questionnaire surveys on a large scale in the relevant populations. However, for the present purposes, I turn to another study of autobiographical narrative (Wortham 2001, 2003) to see whether similar patterning is operating, since the Bakhtinian concept of intertextuality 'radically questions the sociohistorical autonomy of utterances and the radical creativity of language' (Haviland 2005: 81, Bakhtin 1986). Intertextuality is here understood as 'the property [that] texts have of being full of snatches of other texts, which may be explicitly demarcated or merged in, and which the text may assimilate, contradict, ironically echo, and so forth' (Fairclough 1992: 84). In other words, our utterances are full of others' words and we cannot produce discourse without appropriating widely circulating (meta)discourses which carry 'metaculture' as dominant ideas, values, or beliefs in society. 
As we saw in the introduction, Wortham (2001:76-135) analyses a research interview between Jane in her mid-fifties and a psychology graduate student in the United States, and finds that Jane recurrently represented and enacted herself from passive and vulnerable self to active and assertive self in the interview. As can be seen below, passive and vulnerable self is represented by non-agentive grammatical constructions while agentive self is represented and enacted by action verbs.

Table 9. Part of Jane's I-statements

\begin{tabular}{|l|l|}
\hline $\begin{array}{l}\text { Non-agentive self (grammatical } \\
\text { passive or the use of copula 'be') }\end{array}$ & $\begin{array}{l}\text { Agentive self (Jane as a grammatical } \\
\text { agent with action verbs) }\end{array}$ \\
\hline I was regarded as other (117) & I ran away (131) \\
\hline I was ostracized (118) & I went there (132) \\
\hline $\begin{array}{l}\text { I jumped from one space of being } \\
\text { ostracized into another (122-123) }\end{array}$ & I ran away (132) \\
\hline $\begin{array}{l}\text { My mother thought that it would be best } \\
\text { that I be placed in a private school (125) }\end{array}$ & I went to the drug store (132-133) \\
\hline I was there for a year and a half (130) & I called my mother (133) \\
\hline $\begin{array}{l}\text { Evidently my character was being } \\
\text { developed (130-131) }\end{array}$ & $\begin{array}{l}\text { I refused to tell her (134) } \\
\text { I negotiated with her (134-135) }\end{array}$ \\
\hline
\end{tabular}

The numbers in the parentheses refer to the lines in the transcript, which cannot be presented in the present context. However, I point out the fact that on the one hand, the non-agentive self in Table 9 is enacted by the de-quotative $I$ in the pragmatic-semiotic terms, as well as by 'stative' or 'constraint' I-statements in Gee's framework; on the other hand, the agentive self is also enacted by the de-quotative $I$ cued by past tense, though agentive self is enacted by 'action I-statements', which indicates more personal agency. Furthermore, according to Wortham (2001:99), the pattern in Table 9 recurrently occurred in Jane's narrative, and thus the metadiscursive frame is named a 'two-part developmental metadiscourse', which is comparable to the 'success story line' by Shoko, Yoko, and Marco. Now a crucial question that should be asked is: Can it be argued that the 'same' metadiscourse or 'metaculture' is operating in all the interactions? 
By way of summarizing the major findings of the study and at the same time raising crucial issues for discussion, I restate the research questions and briefly answer them. The first question was: (1) how do we know that a certain metadiscursive frame is operating in a given interaction? In order to provide an answer, I focused on indexicality in general and the personal pronoun $I$ in particular in the data, and found the embodied pattern of 'poetic' structure or set of indexical cues collectively presupposing each other to frame an interaction as a particular type of event. Based on the patterning of narrative discourse, I identified the metadiscursive frame of 'a success story line' for my own data and 'two-part developmental metadiscourse' for Wortham's data.

The second question was: (2) how do we know that a certain metadiscursive frame is widely circulating in society? To tentatively answer the question, I compared my data with those of Wortham, following the Bakhtinian assumption of intertextuality. Arguably, the metadiscursive frame is the 'same' in both cases, and the 'success story line' may be 'metaculture' in US society, if my metacultural judgment is correct.

However, I acknowledge two problems: first, my study and other studies do not share the standards for transcription for rigorous comparisons, as $\mathrm{Du}-$ ranti (2003:334) points out; and secondly, there is the problem of lack of large corpora of narrative for comparative studies (Hill 2005:161-162). Having acknowledged the problems, however, if Shoko's, Yoko's and Marco's narratives are compared with Jane's narrative, there are reasons to believe that my participants and Jane follow a comparable metadiscursive frame, since identification cannot occur unless people presuppose more widely circulating categories and models of identity, [which are] often inflected in specific ways' (Wortham 2003: 206). Thus, the success story line as a metadiscursive frame can be hypothesized as 'metaculture, and exactly how widely circulating the frame is remains to be seen, which can be complemented by kinds of empirical research such as surveying on a large scale in society in addition to interviews.

Finally, the third research question was: (3) what are implications of the findings of my study for understandings of 'postmodernity,' with particular reference to the concept of 'fragmented postmodern subjects' (Jameson 1984)? As we saw above, 'postmodern' participants, whose national identity seemed to have been extremely disrupted by the complex migration patterns in late modernity, demonstrated that they were able to tell coherent, 'poetic' and even hegemonic narratives, rather than incoherent ones (Hill 2005: 169). In other 
words, the claim that it is 'impossible to construct an authentic 'voice' in our postmodern era' (Hill 2005:169) is rather questionable.

However, a question remains: Why were the narratives by my three participants not only 'poetic' but also even 'hegemonic'? I speculate, perhaps rather paradoxically, that they were highly aware of the dominant or 'hegemonic' values in US society because of their 'marginalized' socio-political positionality in the modern nation-states. Thus, they (re)presented their self as a highly 'successful self,' particularly to the Japanese researcher, who was relatively a 'new-comer' and spoke English with a Japanese 'accent' in the situational contingencies. Needless to say, all my participants spoke native-like American English with 'no accent.' Actually Shoko even had a distinctive American southern accent, which is rather stigmatised in US society (Lippi-Green 1997: 202-216, Hodge and Kress 1988: 82).

In the light of the findings, I argue that 'postmodern fragmented subjects' are at least 'partly integrated' (Strauss 1997) rather than totally fragmented. Thus, the statement such as 'the alienation of the subject is displaced by the fragmentation of the subject' (Jameson 1984: 63) is rather questionable at least as far as the study of narrative is concerned. Therefore, we should continue research by assuming the existence of patterns in data. However, it should be noted that the relationships among language, ethnicity and national identity are rather complex in late modernity and the statistical correlation of one language, one nation-state, and ethnic homogeneity should not be assumed in our late modern research context.

\section{ACKNOWLEDGEMENTS}

A shorter and slightly different version of the present paper will be published in 2007 AULla Conference Proceedings. Versions of this paper were presented at the Research Seminar of the Department of Languages and Cultures on 2nd of May in 2006 and the Anthropology Seminar on 12th of May in 2006, both at the University of Otago in Dunedin, New Zealand, as well as at the International Conference on Critical Discourse Analysis at the University of Tasmania, Launceston, Australia on 16th of November in 2005, and at AULLA Congress 2007 on 6th of February at the University of New South Wales, Sydney, Australia. I thank the participants of these events for the feedback, and Ruth Fitzgerald in particular for inviting me to the Anthropology Seminar and providing valuable comments. Also, I benefited from comments by Tim Mehigan at the University of Otago and Rod Maclean at Deakins University. This research is partly supported by the University of Otago Research Grant (UORG) and the Asian Research Centre (ARC) at the University of Otago, to which I am grateful. Finally, I am enormously 
indebted to one of the anonymous reviewers, who provided innumerable insightful comments, constructive criticisms, and editorial suggestions. I cannot acknowledge all the points and hereby thank them for their generosity. All the errors that remain are solely my own.

NOTES

1 The article by Briggs (2003) is a partly self-critical follow-up to his Learning How to Ask: a Sociolinguistic Appraisal of the Role of the Interview in Social Science Research published in 1986, in which Briggs conceptualises interviewing as a speech event, and thus focuses mainly on the settings themselves, rather than the circulation of discourse.

2 Transcription conventions are as follows:

- abrupt breaks or stops (if several, stammering)

? rising intonation

- falling intonation

__ (underline) stress

(o.5) silences timed to the nearest second

[ simultaneous talk by two speakers, with one utterance represented on top of the other and the moment of overlap marked by left brackets

$=$ interruption or next utterance following immediately, or continuous talk represented on separate lines because of need to represent overlapping comment on intervening line

(...) transcriber's comment

: elongated vowel

, pause or breath without marked intonation

\section{REFERENCES}

Bakhtin, M.M. 1986 Speech Genres and Other Late Essays, Austin: University of Texas Press.

Briggs, C.L. 1986 Learning How to Ask: A Sociolinguistic Appraisal of the Role of the Interview in Social Science Research, Cambridge: Cambridge University Press.

Briggs C.L. 2003 'Interviewing, Power/Knowledge, and Social Inequality', in J. F. Gubrium and James A. Holstein (eds) Postmodern Interviewing, Thousand Oaks, CA \& London: Sage: 243-254. 
Bourdieu, P. 1991 Language and Symbolic Power. Cambridge, MA: Harvard University Press.

Duranti, A. 1997 Linguistic Anthropology, Cambridge: Cambridge University Press.

Duranti, A. 2003 'Language as Culture in U.S. Anthropology', Current Anthropology, $44(3): 323-347$.

Fairclough, N. 1989 Language and Power, London: Longman.

Fairclough, N. 1992 Discourse and Social Change, Cambridge: Polity.

Foucault, M. 1980 Power/Knowledge: Selected Interviews and Other Writings, 1972-1977, New York: Pantheon.

Gee, J.P. 1999 An Introduction to Discourse Analysis: Theory and Method, London and New York: Routledge.

Gumperz, J.J. 1992 'Contextualization and Understanding', in A. Duranti and C. Goodwin (eds) Rethinking Context: Language as an Interactive Phenomenon, Cambridge: Cambridge University Press: 229-252.

Gumperz, J.J. 1999 'On interactional sociolinguistic method,' in S. Sarangi and C. Roberts (eds) Talk, Work, and Institutional Order, Berlin: Mouton de Gruyter: $453-472$.

Hanks, W. F. 2001 'Indexicality' in A. Duranti (ed) Key Terms in Language and Culture, Oxford: Blackwell:119-121.

Haviland, J. B. 2005 “Whorish Old Man' and 'One (Animal) Gentleman': The Intertextual Construction of Enemies and Selves', Journal of Linguistic Anthropology 15 (1): 81-94.

Hill, J.H. 2005 'Finding Culture in Narrative', in N. Quinn (ed) Finding Culture in Talk: A Collection of Methods, New York: Palgrave Macmillan.

Hodge, R. and Kress, G. 1988 Social Semiotics, Ithaca: Cornell University Press.

Jakobson, R. 1960 'Closing Statement: Linguistics and Poetics', in T. Sebeok (ed) Style in Language, Cambridge, MA: MIT Press: 350-377. 
Jameson, F. 1984 'Postmodernism, or The Cultural Logic of Late Capitalism' New Left Review 146: 53-92.

Kress, G. and Hodge, R. 1979 Language as Ideology, London: Routledge.

Lee, B. 2001. 'Foreword', in G. Urban, Metaculture: How Culture Moves Through the World, Minneapolis, MN: University of Minnesota Press: ix-xvi.

Quinn, N. (ed) 2005 Finding Culture in Talk: A Collection of Methods, New York: Palgrave Macmillan.

Sapir, E. 1949 'Why Cultural Anthropology Needs the Psychiatrist', in D. G. Mandelbaum (ed) Selected Writings of Edward Sapir in Language, Culture and Personality, Berkeley: University of California Press:569-577.

Sherzer, J. 1987 'A Discourse-Centered Approach to Language and Culture', American Anthropologist 89 (2):295-309.

Silverstein, M. 1985. 'On the Pragmatic "Poetry" of Prose: Parallelism, Repetition, and Cohesive Structure in the Time Course of Dyadic Conversation,' in D. Schiffrin (ed) Meaning, Form, and Use in Context: Linguistic Applications, Washington, DC: Georgetown University Press:181-199.

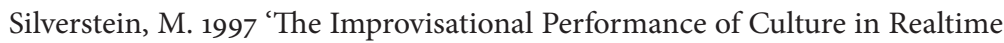
Discursive Practice,' in R. K. Sawyer (ed) Creativity in Performance, Greenwich, CT: Ablex: 265-312.

Silverstein, M. and Urban, G. (eds) 1996 Natural Histories of Discourse, Chicago: University of Chicago Press.

Strauss, C. 1997 'Partly Fragmented, Partly Integrated: An Anthropological Examination of 'Postmodern Fragmented Subjects" Cultural Anthropology 12 (3):362-404.

Urban, G. 1989 'The 'I' of Discourse', in B. Lee and G. Urban (eds) Semiotics, Self, and Society, Berlin and New York: Mouton de Gruyter: 27-51.

Urban, G. 1991 A Discourse-Centered Approach to Culture, Austin: University of Texas Press. 
Urban, G. 2001 Metaculture: How Culture Moves Through the World, Minneapolis, $\mathrm{MN}$ : University of Minnesota Press.

Wortham, S. 2001 Narratives in Action: A Strategy for Research and Analysis, New York: Teachers College Press.

Wortham, S. 2003 'Accomplishing Identity in Participant-Denoting Discourse,' Journal of Linguistic Anthropology 13, 189-210.

Yamaguchi, M. 2005 'Discursive Representation and Enactment of National Identities: The Case of Generation 1.5 Japanese', Discourse \& Society, 16 (2): 269-299. 